\title{
Thermodynamic and kinetic aspects of metal binding to the histidine-rich protein, Hpn
}

\author{
Ruiguang Ge ${ }^{\ddagger}$, Yi Zhang ${ }^{\S}$, Xuesong Sun ${ }^{\ddagger}$, Rory M. Watt ${ }^{\ddagger}$, Qing-Yu He ${ }^{\ddagger}$, Jian-Dong Huang ${ }^{\mathbb{I}{ }^{*}}$, \\ Dean E. Wilcox ${ }^{\S}$, and Hongzhe Sun \\ Department of Chemistry and "Biochemistry, and "Open Laboratory of Chemical Biology, The University of Hong \\ Kong, Pokfulam, Hong Kong, P. R. China; ${ }^{\S}$ Department of Chemistry, Dartmouth College, Hanover, NH 03755-3564
}

\section{Supporting Information}

Experimental materials

Materials. Chemicals were of highest reagent grade, and used without further purification. Stock solutions were prepared by dissolving anhydrous salts in Milli-Q (Millipore) purified water, and adjusted to the desired $\mathrm{pH}$ values with $1.0 \mathrm{M} \mathrm{NaOH}$ or $\mathrm{HCl}$ when needed. E. coli BL21(DE3) (Stratagene) was used to express the hpn gene with the plasmid pET-hpn the construction of which was described previously. ${ }^{7}$ Ampicillin $(100 \mu \mathrm{g} / \mathrm{ml})$ and IPTG $(0.5 \mathrm{mM})$ were added to LB broth when indicated. Bismuth nitrate was purchased from Sigma. Ranitidine bismuth citrate (RBC) was supplied by GlaxoWellcome. Atomic absorption grade standard solutions of $\mathrm{Cu}^{2+}, \mathrm{Zn}^{2+}$ and $\mathrm{Bi}^{3+}$ were obtained from Fluka.

Expression and purification of Hpn. Expression and purification of recombinant Hpn protein was carried out as described previously. ${ }^{7}$ Briefly, a saturated overnight culture of E. coli BL21(DE3) pre-transformed with the Hpn-expression plasmid pET-hpn was diluted into LB media supplemented with $100 \mu \mathrm{g} / \mathrm{mL}$ ampicillin, $0.5 \mathrm{mM} \mathrm{NiSO}$, $0.5 \%$ glucose, and grown at $37^{\circ} \mathrm{C}$ until an $\mathrm{OD}_{600}$ of 0.7 was reached. Protein expression was induced with the addition of IPTG $(0.5 \mathrm{mM})$, and the cultures were then incubated for an additional 4 hours at $37^{\circ} \mathrm{C}$, before chilling to $4^{\circ} \mathrm{C}$. Cells were harvested, and then resuspended in $10 \mathrm{~mL}$ of ice-cold Buffer A (20 mM sodium phosphate buffer, $500 \mathrm{mM} \mathrm{NaCl}, 100 \mathrm{mM}$ imidazole, $1 \mathrm{mM}$ PMSF, $\mathrm{pH}$ 7.4) per liter of cell culture. Bacteria were ruptured by sonication in the presence of $1 \% \mathrm{v} / \mathrm{v}$ Triton X-100. The lysate was centrifuged at $30000 \mathrm{~g}$ for $30 \mathrm{~min}$. The supernatant was filtered through a $0.45 \mu \mathrm{m}$ cellulose acetate syringe filter (Iwaki Glass, Japan), and loaded onto a home-made Ni-NTA resin column (1 mL, Roche) pre-equilibrated with Buffer A. The column was washed with $10 \mathrm{~mL}$ of Buffer A, and then Hpn protein was eluted with $4 \mathrm{~mL}$ of Buffer B $(20 \mathrm{mM}$ sodium phosphate buffer, $500 \mathrm{mM} \mathrm{NaCl}, 500 \mathrm{mM}$ imidazole, $\mathrm{pH}$ 7.4). The fractions containing recombinant Hpn protein, as determined by SDS-PAGE, were pooled, concentrated (Centricon YM-3, Millipore), and then further purified by gel filtration chromatography on Superdex 75 10/300 column (Amersham Biosciences) in a buffer appropriate for subsequent use. Protein concentrations were determined by Bradford's method using bovine serum albumin (BSA) as the standard.

Metal binding mode of recombinant Hpn probed with equilibrium dialysis and ICP-MS. Binding of $\mathrm{Cu}^{2+}, \mathrm{Zn}^{2+}$ and $\mathrm{Bi}^{3+}$ to Hpn was determined with equilibrium dialysis. The dialysis tubes (molecular weight cut-off: $1 \mathrm{kDa}$ ), filled with $200 \mu \mathrm{L}$ of proteins $(5 \mu \mathrm{M})$, were placed into $1.0 \mathrm{~L}$ of $20 \mathrm{mM}$ HEPES, $100 \mathrm{mM}$ $\mathrm{NaCl}(\mathrm{pH} 7.4)$ supplemented with a series of concentrations of $\mathrm{Cu}^{2+}\left(\right.$ as $\left.\mathrm{CuSO}_{4}\right), \mathrm{Zn}^{2+}$ (as $\left.\mathrm{ZnSO}_{4}\right)$ and $\mathrm{Bi}^{3+}$ (as $\mathrm{Bi}\left(\mathrm{NO}_{3}\right)_{3}$ dissolved in dilute glycerol) from 0 to $100 \mu \mathrm{M}$ for overnight at $4^{\circ} \mathrm{C}$. The concentrations of copper, zinc and bismuth inside and outside the dialysis tubes were determined by ICP-MS. Each assay was repeated in triplicate. The results were subjected to Hill analysis for the determination of the stoichiometry and the binding affinity.

Kinetics of nickel release. Fifteen molar equivalents of $\mathrm{Ni}^{2+}$ (as $\mathrm{NiSO}_{4}$ ) were added to $50 \mu \mathrm{M}$ recombinant Hpn protein in $20 \mathrm{mM}$ HEPES, $100 \mathrm{mM} \mathrm{NaCl}$ at pH 6.8 (the $\mathrm{pH}$ value where nickel release starts. ${ }^{7}$ ), 7.4 (physiological $\mathrm{pH}$ used in equilibrium dialysis metal binding experiments) or 8.0 (a higher $\mathrm{pH}$ used in other metal binding experiments). After 1 hour incubation in room temperature, excess nickel ions were removed with a PD-10 desalting column (Amersham Biosciences). Kinetics of nickel release from these Hpn samples by EDTA $(0.5,1,2,3,5,8,12 \mathrm{mM})$ were monitored with the absorbance at $335 \mathrm{~nm}$ using a Varian Cary $3 \mathrm{E}$ $\mathrm{UV} / \mathrm{visible}$ spectrophotometer equipped with a thermostated cell maintained at $25^{\circ} \mathrm{C}$. All assays were measured against a reference of buffer (20 mM HEPES, $100 \mathrm{mM} \mathrm{NaCl}$ at $\mathrm{pH} 6.8$ or 8.0) supplemented with appropriate concentrations of EDTA.

Nickel release kinetics by competition with EDTA followed the reported method for measuring iron release from ferric iron binding protein (FbpA) with EDTA (Dhungana, S.; Anderson, D. S.; Mietzner, T. A.; Crumbliss, A. L. Biochemistry 2005, 44, 9606-9618)

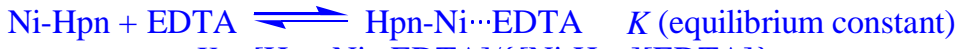

$$
\begin{aligned}
& K=[\mathrm{Hpn}-\mathrm{Ni} \cdots \text { EDTA }] /\{[\mathrm{Ni}-\mathrm{Hpn}][\mathrm{EDTA}]\} \\
& \text { Hpn-Ni } \cdots \text { EDTA } \stackrel{k_{2}}{\longrightarrow} \mathrm{Ni} \text {-EDTA + Hpn } \\
& \text { Rate }=k_{2}[\mathrm{Hpn}-\mathrm{Ni} \cdots \mathrm{EDTA}]
\end{aligned}
$$


The concentration of Hpn-Ni..EDTA can not be measured directly. However, the total concentration of Ni-Hpn and Hpn-Ni...EDTA is measurable since it is the initial concentration of the protein. Therefore the apparent rate constant can be rewritten as:

$$
k_{\mathrm{obs}}=k_{2}[\mathrm{EDTA}] /\{[\mathrm{EDTA}]+(1 / K)\}
$$

Metal ions susceptibility in $\boldsymbol{E}$. coli. E. coli BL21(DE3) cultures, both with and without the plasmid pEThpn (inoculated from individual colonies) were grown in LB media (containing $100 \mu \mathrm{g} / \mathrm{mL}$ ampicillin when required), at $37^{\circ} \mathrm{C}$. Stationary phase, overnight cultures $(20 \mu \mathrm{L})$ were added to $2 \mathrm{ml}$ of fresh medium supplemented with metal ions: $\mathrm{NiSO}_{4}(50-500 \mu \mathrm{M})$; RBC $(5-100 \mu \mathrm{g} / \mathrm{mL})$; $\mathrm{CuSO}_{4},(1-5 \mathrm{mM})$, or $\mathrm{ZnSO}_{4}(0.2-$ $20 \mathrm{mM})$, and incubated for $12\left(\mathrm{NiSO}_{4}, \mathrm{CuSO}_{4}\right.$, and $\left.\mathrm{ZnSO}_{4}\right)$ or $8(\mathrm{RBC})$ hours at $37^{\circ} \mathrm{C}$, with IPTG added where applicable to a final concentration of $0.5 \mathrm{mM}$ when the $\mathrm{OD}_{600}$ was approximately 0.6 .

Electron paramagnetic resonance (EPR). EPR spectra were obtained on a Bruker EMX-300 spectrometer with the spectral parameters of $100 \mathrm{KHz}$ modulation frequency, $1.0 \mathrm{G}$ modulation amplitude and $20 \mathrm{~ms}$ time constant. Solutions containing $0.1 \mathrm{mM} \mathrm{Hpn}$ and 0.1 or $0.5 \mathrm{mM} \mathrm{Cu}{ }^{2+}$ were prepared in 100 $\mathrm{mM}$ Tris buffer ( $\mathrm{pH} 8.1)$ and EPR spectra were recorded on $400 \mu \mathrm{L}$ of these solutions in quartz EPR tubes at $77 \mathrm{~K}$ in a liquid nitrogen finger dewar.

\section{Complete reference of 5 a}

5. (a) Tomb, J.-F.; White, O; Kerlavage, A. R.; Clayton, R. A.; Sutton, G. G.; Fleischmann, R. D.; Ketchum, K. A.; Klenk, H. P.; Gill, S.; Dougherty, B. A.; Nelson, K.; Quackenbush, J.; Zhou, L.; Kirkness, E. F.; Peterson, S.; Loftus, B.; Richardson, D.; Dodson, R.; Khalak, H. G.; Glodek, A.; McKenney, K.; Fitzegerald, L. M.; Lee, N.; Adams, M. D.; Hickey, E. K.; Berg, D. E.; Gocayne, J. D.; Utterback, T. R.; Peterson, J. D.; Kelley, J. M.; Cotton, M. D.; Weidman, J. M.; Fujii, C.; Bowman, C.; Watthey, L.; Wallin, E.; Hayes, W. S.; Borodovsky, M.; Karp, P. D.; Smith, H. O.; Fraser, C. M.; Venter, J. C. Nature 1997, 388, 539-547. 